\title{
Ophthalmological manifestation of the Klippel Trenaunay Syndrome
}

\author{
Manifestações oftalmológicas de \\ Sindrome de Klippel Trenaunay
}

Carlos Augusto Moreira Júnior ${ }^{1}$, Carlos Augusto Moreira Neto², Nicole Tássia Amadeu³, Mariela Regina Dalmarco Ghem³

\begin{abstract}
The Klippel-Trenaunay Syndrome (KTS) is a rare congenital disease, which the prevalence is higher in males, and its incidence of 25:100,000. It is presented in its classic form as the triad of port-wine stains, enlarged limbs and venous and / or lymphatic malformation. The diagnosis is essentially clinical and due to the complexity of the syndrome, the progressive characteristic and the wide variety of clinical presentations, a multidisciplinary team should treat patients individually. The ocular changes associated with KTS include vascular, orbit, iris, retina, choroid and optic nerve abnormalities. Case report: A 23-year-old female patient, carrier KTS, being followed at Vision Center - Federal University of Paraná, complaining of decreased visual acuity in the right eye. The patient had port-wine stains in right hemibody and hypertrophy of ipsilateral members. Glaucoma was diagnosed and eye exams were performed to assess the degree of impairment of visual fields and fundus. The best correction was checked at 20/100 OD and 20/20 OS. At fundoscopy, there was increased excavation of the optic nerve right $-0.75 \times 0.90 \mathrm{~mm}$. Clinical treatment was chosen with Dorzolamide Hydrochloride, Latanoprost, Brimonidine and Timolol, presenting good long-term results - the tonometry showed $19 \mathrm{mmHg} O \mathrm{OD}$ and $15 \mathrm{mmHg} O \mathrm{OS}$, despite the difficulty in stabilizing the disease. Conclusion: Reports have shown that the results of clinical and surgical treatments of glaucoma in association with KTS are unsatisfactory compared to other types of glaucoma - clinical control is not possible in about 1/ 3 of patients and the surgical management has a high rate of complications. Significant studies are needed to establish the correlation between glaucoma and KTS, and base the treatment of choice.
\end{abstract}

Keywords: Glaucoma/complications; Glaucoma/diagnosis; Klippel-Trenaunay-Weber syndrome; Capillaries/abnormalities

\begin{abstract}
RESUMO
A Síndrome de Klippel-Trenaunay (SKT) é uma doença congênita rara, com maior prevalência no sexo masculino e incidência de 25:100.000. Apresenta-se, na forma clássica, como a tríade de manchas vinho porto, hipertrofia de membros e malformação venosa e/ou linfática. O diagnóstico é essencialmente clínico e devido à complexidade da síndrome, de natureza progressiva e ampla variedade de apresentações clínicas, os pacientes devem ser tratados de forma individualizada por uma equipe multidisciplinar. .Alterações oftalmológicas associadas à SKT incluem anormalidades vasculares da órbita, íris, retina, coroide e nervo óptico. Relato de caso: Paciente de 23 anos, sexo feminino, portadora de SKT, em acompanhamento no Centro da Visão - Universidade Federal do Paraná, com queixa de diminuição da acuidade visual em olho direito. A paciente apresentava manchas vinho porto em dimidio direito e hipertrofia de membros ipsilateral. Foi diagnosticado glaucoma e realizados exames complementares oftalmológicos a fim de avaliar o grau de comprometimento dos campos visuais e o fundo de olho. A visão com a melhor correção foi de 20/100 OD e foi de 20/20 OE. À fundoscopia, constatou-se aumento da escavação do nervo óptico à direita $-0,75$ x 0,90 mm. Optou-se por tratamento clínico com Cloridrato de Dorzolamida, Latanoprosta, Brimonidina e Timolol, com bons resultados a longo prazo - a tonometria de aplanação mostrou $19 \mathrm{mmHg}$ OD e $15 \mathrm{mmHg}$ OE, apesar da dificuldade na estabilização da doença. Conclusão: Relatos demonstram que os resultados dos tratamentos clínico e cirúrgico do glaucoma em associação à SKT são insatisfatórios quando comparados a outros tipos de glaucoma - o controle clínico não é possível em cerca de 1/3 dos pacientes, e o manejo cirúrgico tem alto índice de complicações. São necessários estudos mais expressivos que estabeleçam a correlação entre glaucoma e SKT e embasem o tratamento de escolha.
\end{abstract}

Descritores: Glaucoma/complicações; Glaucoma/diagnóstico; Síndrome de Klippel-Trenaunay-Weber; Capilares/anormalidades.

\footnotetext{
${ }^{1}$ Ophthalmology Department of Universidade Federal do Paraná, Curitiba, PR, Brazil.

${ }^{2}$ Hospital de Olhos de Curitiba, PR, Brazil.

3 Medicine School of Universidade Federal do Paraná, Curitiba, PR, Brazil.

Study carried out at Centro da Visão do Hospital de Clínicas da Universidade Federal do Paraná, Curitiba, PR, Brazil.

The authors declare no conflicts of interests.

Received for publication 02/06/2015 - Accepted for publication 27/10/2015
} 


\section{INTRODUCTION}

$\mathbf{I}$

n 1900, Klippel and Trenaunay described a rare congenital malformation characterized by abnormalities in mesodermal

components. The incidence of SKT, more prevalent in males, is 2-5:100,000, and its pathogenesis has not yet been completely clarified. ${ }^{(1)}$ Studies suggest that the majority of cases results from somatic mutations involving genes responsible for embryonic angiogenesis.

The classic description of Klippel-TrenaunaySyndrome (KTS) is clinically defined by the triad:(1) capillary malformation, often port wine stain, in the affected extremity or at another location other than the hypertrophied limb; (2) bone or soft tissue hypertrophy, or both; (3) varicose veins and venous malformations, sometimes with persistent embryogenic lateral veins. Two of the three manifestations are necessary for the diagnosis of KTS.The lesions shall be present at birth, and in about $75 \%$ of patients it appears before 10 years of age, with no tendency to involution. ${ }^{(1-5)}$

Ophthalmologic changes associated to KTS include vascular abnormalities of the orbit, iris, retina, choroid, and optic nerve.The findings include:orbital varices, retinalvaricoses, choroidal and melanomaangioma, persistent fetal vasculature, heterochromia iridum, strabismus and glaucoma. ${ }^{(5-7)}$

\section{Case RePort}

F.M.P, female, 23 years old, from Irati, Paraná,went to Centro da Visão da Universidade Federal do Paraná (UFPR) in Curitiba, Paraná, in order to re-evaluate the visual acuity and glaucoma.

The patient reported previous diagnosis of glaucoma in $\mathrm{RE}$ associated to asymmetry of lower limbs and wine-colored stains in the right hemibody since childhood.She denies other comorbidities or family history of glaucoma or similar cases.In use of ophthalmic solutionsof Dorzolamide Hydrochloride, Latanoprost and Combigan (Brimonidine + Timolol).

The physical examination showed port wine stains on right hemibody(Figures 1A, 1B and 1C) and left lower limb hypertrophy.

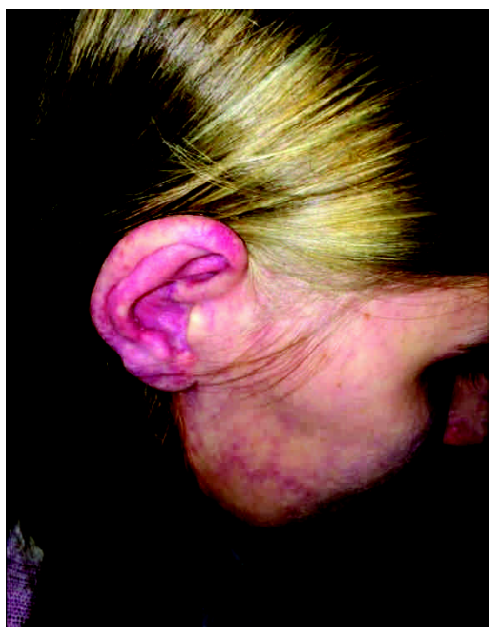

Figure 1A: Portwine stains in the right hemiface, including the right ear Source: The author (2015)

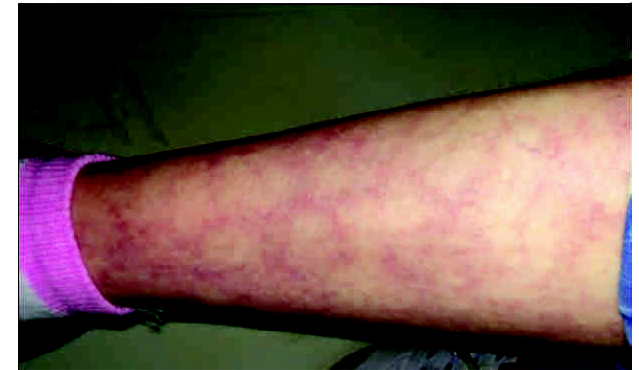

Figure 1B: Portwine stains in the right lower limb Source: The author (2015)

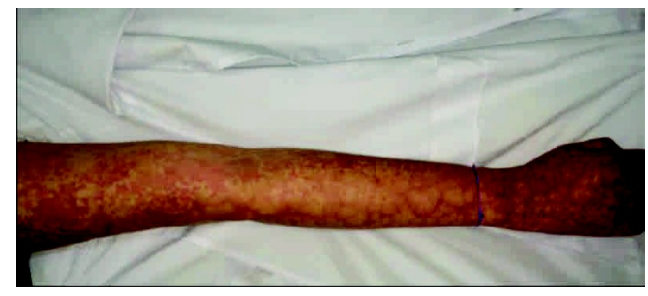

Figure 1C: Portwine stains on the right upper limb Source: The author (2015)

On examination, the patient showed buphthalmos in RE (Figure 2), with extrinsic motility preserved.In the examination of motor skills and eye sensitivity, the pupils were isochoric and photoreactive, and reflections of pairs of NC III, IV, V and VI were preserved.The endoscopy showed the presence of bilateral red reflex and increased excavation of the optic nerve to the right $-0.75 \times 0.90 \mathrm{~mm}$ (Figure 3 ).

The RE had the best correction of 20/100, and the LE was 20/20. Applanation tonometry showed $19 \mathrm{mmHg}$ in RE and $15 \mathrm{mmHg}$ in LE.Biomicroscopy evaluation of the optic nerve showed asymmetry between the excavations of both eyes, with increased excavation / disc ratio in RE, denudation of circunlinear vessel, diffuse arteriolar narrowing, peripapillary atrophy, and located pallor in the neuroretinal rim.

Perimetry showed peripheral loses of visual field in RE.In order to evaluate the functional damage of glaucoma, Linear Computerized Perimetry, strategy Fastpav 24-2 was used (Figure 4).

The measurement of the retinal nerve thickness in REwith nerve fibers analyzer OCT-GDx showed loss of Double hump (physiological peaks in the upper and lower regions), with areas outside normal limits, and decreased thickness in the upper, bottom and central areas $(95 \% \mathrm{CI})$; temporal region within the normal range (Figure 5).

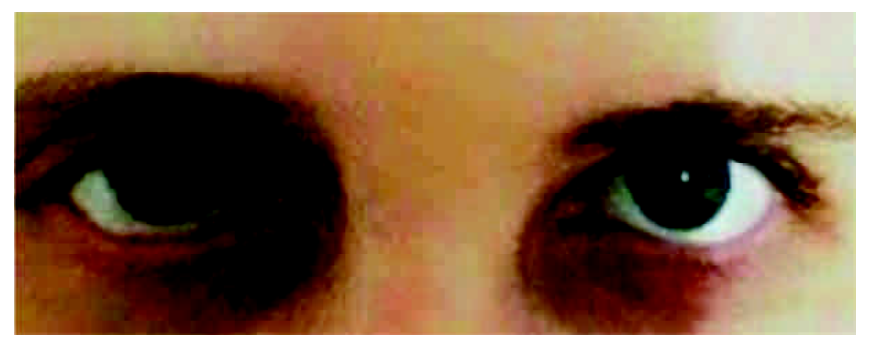

Figure 2: Buphthalmos in the right eye Source: The author (2015) 


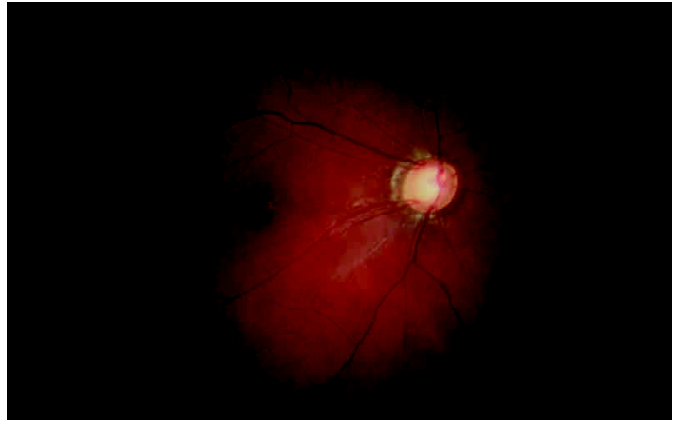

Figure 3: Fundoscopy of the right eye Source: The author (2015)

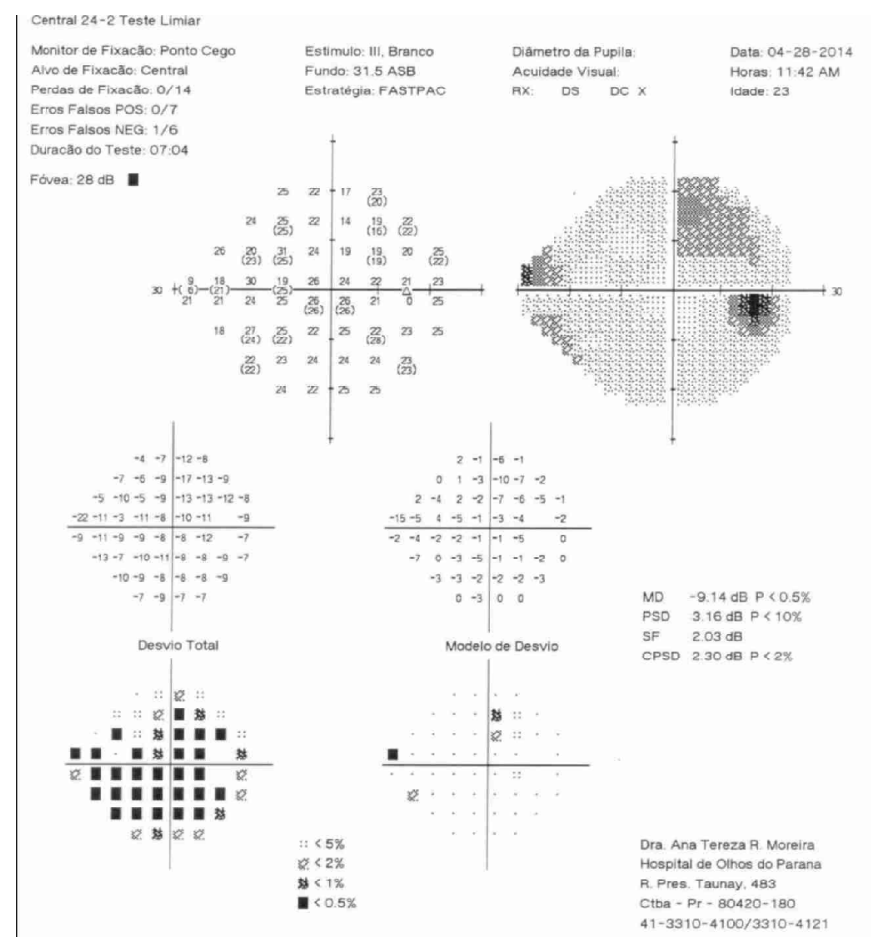

Figura 4: Linear computer perimetry of RE Source:The author (2015)

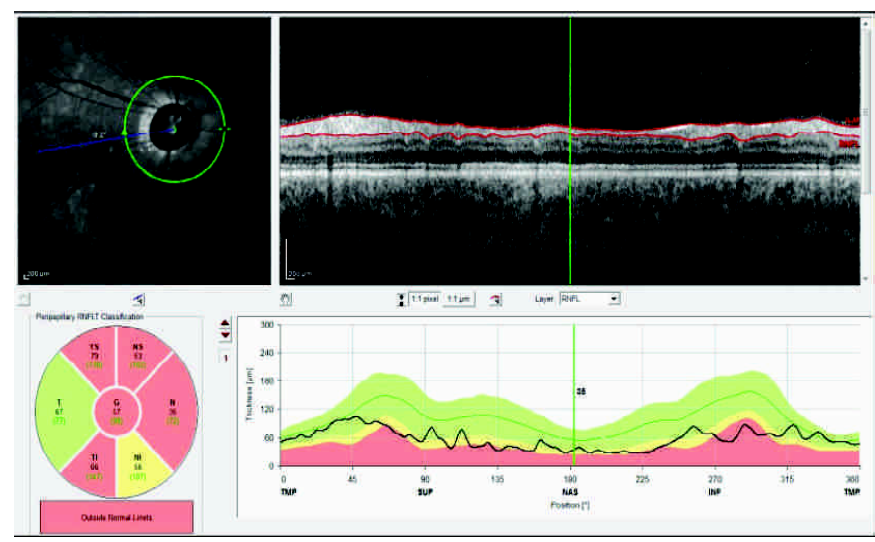

Figure 5: Measurement of the retinal nerve thickness in RE witn verve fibers analyzer OCT-GDX

Source: The author (2015)

\section{Discussion}

SKT has been used as a synonym of Klippel-TrenaunayWeber Syndrome (KTWS) ${ }^{(2)}$ The Sturge-Weber Syndrome (SWS), also a sporadic and rare neuro-oculocutaneous congenital malformation, is characterized by encefalofacialangiomatosis -. port wine stains of the face, most commonly following the distribution of NC III; glaucoma and vascular lesions of the ipsilateral side of the brain and meninges. ${ }^{(2)}$ However, the KTWS is considered a separate entity, consisting of the triad KlippelTrenaunayaccompanied by a clinically apparent arteriovenous fistula characteristic of SWS, a component indicating the worst prognosis..$^{(4,5)}$ The incidence of SWS is $1: 50,000^{(8)}$, and there is no racial or gender difference ${ }^{(9)}$, whereas KTS is more prevalent in males, 2-5: 100,000. The association between SWS and KTS resulting in KTWS is not usual. ${ }^{(2)}$

In 1956, Schnyder et al. ${ }^{(10)}$ correlated Klippel-Trenaunay, Sturge-Weber and Klippel-Trenaunay-Weber syndromes, also called Parkes-Weber syndrome.They suggested that the three syndromes are variants with the same main characteristic - local gigantism and hemangioma.The involvement of the head and neck, with meningeal angiomatosis, causing epileptic seizures and choroidal hemangioma or glaucoma, results in SWS.Gigantism and hemangioma in the limbs with bone hypertrophy are characteristic of KTS, KTWS, in case of significant arteriovenous malformation.Due to the similar behavior of the syndromes, it is suggested that they have the same basic pathophysiology, showing different manifestations due to the involvement typical of each one of them. The other characteristics should be secondary to the primary involvement of neuro-ectodermal vascularity. ${ }^{(2)}$

The pathogenesis of these syndromes has not been completely explained yet.Studies suggest that the majority of cases results from somatic mutations involving genes responsible for embryonic angiogenesis.Until now, no locus or specific gene was identified as the source of the malformation. ${ }^{(2,5)}$ Recent studies have shown some evidence that KTWS is associated to the translocation $\mathrm{t}(8 ; 14)$ (q22.3; q13). Men and women are equally affected in KTWS, and the occurrence is not limited nor has a preferred racial group. ${ }^{(11)}$

Clinical presentations can be extremely varied. ${ }^{(12)}$ A study with 252 patients with Klippel-Trenaunay-Weber Syndrome found the classic triad in $63 \%$ of patients.Almost all (98\%) the cases had capillar malformations with portwine stains, $72 \%$ showed arteriovenous malformations, and $67 \%$ had limb hypertrophy. ${ }^{(13)}$

The lesions shall be present at birth, and in about $75 \%$ of patients it appears before 10 years of age.The portwine stain is present at birth and does not show any tendency to develop.It is often unilateral and segmented -in general respecting the midline - and increases proportionally to the growth, besides the possibility to be present in any part of the body, being more common in the face and neck of patients with SWS. ${ }^{(14)}$ The most frequent findings are isolated to one limb in KTS.However, there are reports of cases involving more than one limb, hemibody, and even the whole body. ${ }^{(12)}$

Ophthalmologic changes associated to KTS and KTWS include vascular abnormalities of the orbit, iris, retina, choroid, and optic nerve.The findings include:orbital varices, retinal varicoses, choroidal and melanoma angioma, persistent fetal vasculature, heterochromia iridum, strabismus and glaucoma. ${ }^{(5-7)}$

Several other abnormalities involving the optic nerve have been described in association with KTWS.Good and Hoyt ${ }^{(15)}$ 
reported in 1989 the case of a patient, female, 10 years of age, with KTWS and increased shade of the optic nerve at ecography(thickening of the optic nerve).Spoor et al. ${ }^{(16)}$ described in 1981 the case of a patient, female, 18 years of age, with KTWS and bilateral meningeoma in the optic nerve.Bothun et al. ${ }^{(5)}$ reported in 2011 the case of a 16-year-old girl with KTS associated to bilateral glioma of the optic chiasm and optic nerves, druses in the optic disc, and acquired myelinationof the retinal nerve fibers.In addition, cases of optic nerve hypoplasia, reverse papilla, and conjunctival linfangiectasia have already been documented. ${ }^{(17)}$

Fundus abnormalities associated to Klippel-TrenaunayWeber syndrome are not common, and include retinal vascular tortuosity and diffuse choroidal hemangioma. ${ }^{(18)}$

Due to the complexity of the syndrome, its progressive nature and wide variety of clinical presentations, patients must be treated individually by a multidisciplinary medical team. ${ }^{(12)}$

The management of SKT is predominantly conservative, including compressive therapies such as the use of compression stockings and even intermittent pneumatic compression of the limb affected. ${ }^{(12,13,19)}$ These therapies help to reduce symptoms of venous insufficiency and lymphedema, but they are not effective to decrease the size of the hypertrophied limb. ${ }^{(8)}$ Surgery, laser therapy, sclerotherapy and embolic therapy can also be used.The prognosis of the disease can be reserved in some cases - the presence of important arteriovenous malformation in KTWS indicates severity and risk of loss of the affected limb. ${ }^{(12)}$

In patients with functional limbs, little or no edema, bleeding, ulceration or pain, the treatment of choice is conservative focused on relief of symptoms.Pulsed laser light therapy was used with excellent clinical efficacy and good aesthetic results in the treatment of portwine stains on the face and neck.The surgical indication is reserved for an increase greater or equal to $2 \mathrm{~cm}$ of the hypertrophied limb, in comparison with the contralateral limb. ${ }^{(12)}$

About the ocular repercussions, the standard treatment for glaucoma has been the continued drug treatment combined with surgeries ${ }^{(20)}$ in order to control the intra ocular pressure and prevent damage to the optic nerve.Nevertheless, the initial treatment is carried out only with beta-blockers, carbonic anhydrase inhibitors, alpha-agonists, and analogues of prostaglandins. ${ }^{(21)}$

Surgical procedures are only for patients who do not respond to clinical treatment, but the abnormality in the vasculature and high episcleral venous pressure compromise the success of the surgery. ${ }^{(20)}$ In the case of large circumscribed choroidal hemangiomas with subretinal fluid, treatment with episcleralbrachytherapy plate is often considered effective. ${ }^{(22)}$ However, researchers report results of clinical and surgical treatment forglaucoma in SWS patients as unsatisfactory compared to other types of glaucoma. The clinical control is not possible in about $1 / 3$ of the patients, and the surgical management can be difficult.

The surgical technique is still debatable, a challenge for ophthalmologists because of the high rate of postoperative complications such as choroidal hemorrhage in these patients. ${ }^{(23)}$

\section{REFERENCES}

1. Forbes N, Walwyn M, Rao G, Ellis D, Lee MG. Klippel-Trenaunay syndrome. West Indian Med J. 2013;62(3):254-6.

2. Purkait R, Samanta T, Sinhamahapatra T, Chatterjee M. Overlap of Sturge-Weber syndrome and Klippel-Trenaunay syndrome. Indian J Dermatol. 2011;56(6):755-7.
3. Geske JB, Jouni H, Hoyt JR. Images in vascular medicine. The mystery of a crimson leg: a case of Klippel-Trenaunay-Weber syndrome. Vasc Med. 2013;18(1):49-50.

4. Meier S. Klippel-Trenaunay syndrome: a case study. Adv Neonatal Care. 2009;9(3):120-4

5. Bothun ED, Kao T, Guo Y, Christiansen SP. Bilateral optic nerve drusen and gliomas in Klippel-Trenaunay syndrome. J AAPOS. 2011;15(1):77-9.

6. Dhir L, Quinn AG. Persistent fetal vasculature and spontaneous hyphema in a patient with Klippel-Trénaunay-Weber syndrome. J AAPOS. 2010;14(2):190-2.

7. Brodsky MC. Circumpapillary choroidal "haemorrhoid" in KlippelTrenauney-Weber syndrome. Br J Ophthalmol. 2007;91(3):394.

8. Di Rocco C, Tamburrini G. Sturge-Weber syndrome. Childs Nerv Syst. 2006;22(8):909-21.

9. Pascual-Castroviejo I, Díaz-Gonzalez C, García-Melian RM, Gonzalez-Casado I, Muñoz-Hiraldo E. Sturge-Weber syndrome: study of 40 patients. Pediatr Neurol. 1993 1993;9(4):283-8.

10. Schnyder UW, Landolt E, Martz G. Syndrome de KlippelTrenaunay avec colombe irien atypique. J Genet 1956;5:1-8.

11. Dutt R, Dutt C. Klippel - trenaunay - weber syndrome. J Clin Neonatol. 2012;1(3):160-1.

12. Kihiczak GG, Meine JG, Schwartz RA, Janniger CK. KlippelTrenaunay syndrome: a multisystem disorder possibly resulting from a pathogenic gene for vascular and tissue overgrowth. Int J Dermatol. 2006;45(8):883-90.

13. Jacob AG, Driscoll DJ, Shaughnessy WJ, Stanson AW, Clay RP, Gloviczki P. Klippel-Trénaunay syndrome: spectrum and management. Mayo Clin Proc. 1998;73(1):28-36.

14. Gontijo B, Pereira LB, Silva CM. Malformações vasculares. An Bras Dermatol. 2004;79(1):7-25.

15. Good WV, Hoyt CS. Optic nerve shadow enlargement in the Klippel-Trenaunay-Weber syndrome. J Pediatr Ophthalmol Strabismus. 1989;26(6):288-9.

16. Spoor TC, Kennerdell JS, Maroon JC, Hepler R, Krohel G. Pneumosinus Dilatans, Klippel-Trenaunay-Weber syndrome, and progressive visual loss. Ann Ophthalmol. 1981;13(1):105-8.

17. Belliveau MJ, Brownstein S, Jackson WB, Yücel YH. Bilateral conjunctival lymphangiectasia in Klippel-Trénaunay-Weber syndrome. Arch Ophthalmol. 2009;127(8):1057-8.

18. Brod RD, Shields JA, Shields CL, Oberkircher OR, Sabol LJ. Unusual retinal and renal vascular lesions in the Klippel-TrenaunayWeber syndrome. Retina. 1992;12(4):355-8.

19. Gloviczki P, Driscoll DJ. Klippel-Trenaunay syndrome: current management. Phlebology. 2007;22(6):291-8.

20. Bodensteiner JB; Roach E.S. Sturge-Weber syndrome. NJ: The Sturge-Weber Foundation, 1999.

21. van Emelen C, Goethals M, Dralands L, Casteels I. Treatment of glaucoma in children with Sturge-Weber Syndrome. J Pediatr Ophthalmol Strabismus, 2000;37(1):29-34.

22. Franco Neto NB, Franchini SP, Foletto Junior VG, Pomblum VJ. Síndrome de Sturge-Weber. Saúde (Santa Maria), v.37, n.2, p. 0918, 2011.

23. Figueiredo LR, Silva Filho SJ, Rehder JR. Sturge-Weber syndrome and its ocular effects: a review. Rev Bras Oftalmol. 2011;70(3):194-9.

\section{Corresponding author:}

Carlos Augusto Moreira Neto

Centro da Visão:Rua Pasteur, 26, District: Batel, Curitiba, Paraná,

Brazil, ZIP Code:80250-080 -

Phone: (41) 3360-1800

Email:moreiraguto@hotmail.com

Nicole TássiaAmadeu

Email:niamadeu@gmail.com 